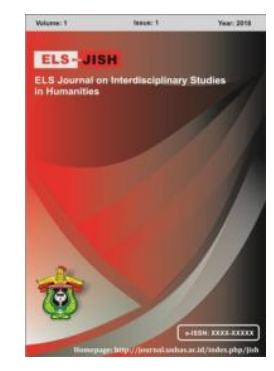

ELS-JISH

ELS Journal on Interdisciplinary Studies on Humanities

Volume 3 Issue 1, 2020

ISSN (print) : 2621-0843

ISSN (online) : 2621-0835

Homepage : http://journal.unhas.ac.id/index.php/jish

\title{
Context of Situation in Students' Textbook: A Pragmatic Study
}

\author{
Aulia Wahyu Santosa ${ }^{1}$, Endang Fauziati ${ }^{2}$, Slamet Supriyadi ${ }^{3}$ \\ ’aulia.ws@yahoo.com
}

\begin{abstract}
This research study is a pragmatic analysis which focuses on context of situation in English Textbook. The objective of the study is to describe the four components of context of situation in the dialogues contains in the textbook. This research applies descriptive qualitative type. By applying this method, the researcher uses the dialogues in one unit of textbook as the data source, while the data of the research are the elaboration of each component of the dialogues. The result of the research show that although there are some components of context of situation that is stated implicitly or even unclear, the ideas of the dialogue are still can be understood
\end{abstract}

Keywords: Context of Situation, Pragmatics, Textbook

How to cite: Santosa, A. W., et. al. (2020). Context of Situation in Students' Textbook: A Pragmatic Study. ELS Journal on Interdisciplinary Studies in Humanities, 3(1), 130-139. DOI: http://dx.doi.org/10.34050/els-jish.v3i1.9521

\section{Introduction}

In the human being society, communication is a basic human activity, and the basis of all human communication is called language. Language is significant since it is a means of communication. Through language, people are able to share messages, their thoughts and express their feelings. Language is the system of sounds and words used by humans to express their thoughts and feelings (Hornby, 1995:662).

The function of language is to communicate. Lubis (1988: 10) says that one form of communication is the interaction between speakers. The interaction includes the way speakers convey meaning and express their feelings, what people do with words and utterances and then form good sentences to be sent to other speakers. However, misunderstanding can always occur in daily life conversation, because the speakers do not find appropriate words to express their feelings, even though the speakers try to use the media of communication properly. Since it deals with the message being conveyed, one way to overcome this is to have what so called communicative competence. As stated by Hymes (1972), communicative competence is the knowledge that enables someone to use a language effectively for real communication, which involves

${ }^{1,2,3}$ Universitas Sebelas Maret, Indonesia. 
two or more speakers. These speakers interact with each other in the form of oral or written communication and stimulate each other to respond to what each says.

According to Murcia (1995), there are five components of communicative competence; discourse competence, linguistic competence, actional competence, sociocultural competence, and strategic competence. The component of communicative competence that relates to the way someone convey and understand their intent in communication is what we call actional competence. This competence involves knowledge of how speech acts and language functions are patterned and sequenced in real-life situations (Celce Murcia et. al., 1995:17-21).

In addition, since this knowledge not only studies the acts uttered by the speakers but also studies the meaning of words in context, such as analyzing the parts of meaning that can be explained by knowledge of the physical and social world as well as the knowledge of the time and place in which the words are uttered or written, analyzing a language contained in the dialogues of English textbooks through pragmatics is comprehensive in this case. Therefore, pragmatic analysis of linguistic does not only involve the analysis of linguistic form, but also the interpretation of what people mean in a particular context and how the context influences what is said.

Realizing that situation, there are many schools and English courses that aim to help Indonesian people to acquire English. However, learning English is a systemic process that takes time to acquire. English is a foreign language to Indonesian students, both children and adults. Likewise, in some countries, it is also used as the second language besides the national language. In his writing, McKay (2003) claims that English popularity is not solely native countries' efforts to spread their language but more to the awareness of the world community of the importance of mastering English. It cannot be denied that globally, various worlds' information's are contained in English so that to access it, people must have their own proficiency of the language. It corresponds to the government's decision to establish English as a school subject in various level of education.

One of the tools or media used to learn English in school is textbook. In this case, textbooks emerge as one of the effective alternatives for teachers in giving more exposure to the students to learn English (see Cunningsworth, 1995; Ansary \& Babaii, 2002; Alshumaimeri \& Alzyadi, 2015) and to develop the pragmatic competence for foreign learners in the classroom (Diepenbroek \& Derwing, 2013), especially for those non-native speakers who do not have enough opportunity to fully develop their pragmatic knowledge and skills (Kim \& Hall, 2002). Indonesia's Ministry of Education and Culture has established one particular textbook to be used by all school in $X$ grade of education. It is textbook entitled Bahasa Inggris.

A little attention regarding this field has been given by some researches. Murti in 2017 studied about the context of situation of English Textbook that was established at that time. She found out that all of the components of the contexts of dialogues in the textbook fit the current curriculum, although there 
are many unclear settings of the interaction, the contexts of dialogues are still implicitly in line with the curriculum which occurs in students' environment and student's life. Another study is by Rois (2012). She revealed that the context of situation followed the speech act uttered, which is declarative form. It is used by character in almost all functions of illocutionary act types, such as to inform, convince, state, describe, clarify, argue, request something or someone to do something, express his feeling, refuse, and offer. On the contrary, the imperative is the least performed type. The difference between this research and those studies stated above are that this research tries to analyze the context of situation in English textbook that is nationally used in Indonesia. Second, this research does not analyze all dialogues contained in the textbook, but this only analyzes the context of situation of each dialogue in the certain unit of the textbook. Therefore, the aim of this research is to analyze the context of the situation in the dialogues in the textbook by using components of context of situation by Holmes (2001).

\section{Method}

This research employed descriptive qualitative method since it emphasizes on describing the phenomenon of the use of language in its context by interpreting the data. According to Denzin and Yvona (1994:1), qualitative research is a field of inquiry in its own rights. It crosscuts disciplines, fields, and subject matter. Morse (1994) adds that this method will try to cover the language, the analysis, and description of interpretation. Furthermore, Lithcman $(2010: 12)$ says that its purpose is to describe and understand human phenomena, human interaction, or human discourse. This type of research attempted to describe or explain why a phenomenon happens.

The data collection consists of the description of the types of data collected, the instruments used to collect the data, and technical procedures to use the instruments in collecting the expected data. In line with the evaluation and case study, the type of data collected in this present research was qualitative data. The qualitative data derived from the description of information of the analysis of context of situations-found in the analysis sheets.

\section{Results}

The context of situation followed the speech acts occurred in the textbook. The dialogues in the textbook mostly discuss about someone's achievement which is in line with the analyzed unit, congratulating and complimenting. Therefore, speech act that occur the most are congratulating and complimenting.

\subsection{Participants}

Participants in the context of situation means the speaker(s) and hearer(s) involved in the conversation (Holmes, 1992). The characters of each dialogue could be shown explicitly, implicitly, or unclear. The numbers of dialogues which participants are explicitly and implicitly stated in dialogues as well as those that characters are presented unclearly or with no name is available in table 1 as follows. 
Table 1. Numbers of Participants in the Dialogues

\begin{tabular}{lccc}
\hline \multicolumn{1}{c}{ Participants } & $\begin{array}{c}\text { The Speaker } \\
\text { (P1) }\end{array}$ & $\begin{array}{c}\text { The Hearer } \\
\text { (P2) }\end{array}$ & Examples \\
\hline Explicitly Stated & 5 dialogues & 5 dialogues & Dialogue 1, 2, 3, 4, 5 \\
Unclear/ No name & 5 dialogues & 5 dialogues & Dialogue 6, 7, 8, 9, 10 \\
Total & 10 dialogues & 10 dialogues & \\
\cline { 1 - 2 } & \multicolumn{2}{c}{} &
\end{tabular}

In the table above, it can be seen that the number of each explicitly stated participant is equal. There are 5 dialogues out of 10 dialogues, which explicitly stated in the textbook, such as Samuel, Alif, Sinta, Deni, Santi, Bejo, Ivan, Eny, Bintari, Ditto, Cita, and Rahmi. Meanwhile, there are 5 dialogues containing unclear information of participants. This textbook does not contain any implicit information of participants in its dialogues. The dialogues are whether presented explicitly or unclear. For further information regarding the characters in the textbook are presented in the table 2 below.

Table 2. Characters in the dialogues

\begin{tabular}{cc}
\hline Explicitly stated & Unclear \\
\hline Samuel & A girl wearing orange shirt \\
Alif & A guy with a guitar and microphone \\
Sinta & A boy carrying fishing utilities \\
Deni & A man carrying fish \\
Santi & A girl in a skirt and yellow blouse \\
Bejo & A girl wearing red dress \\
Ivan & A girl wearing yellowi skirt and brown sweeter \\
Eny & A girl wearing wedding gown \\
Bintari & A man wearing black trousers and white t-shirt \\
Ditto & A girl with the painting \\
Cita & \\
Rahmi & \\
\hline
\end{tabular}

It can be seen form the table above that the characters in the dialogues consist of two, the explicitly stated characters and unclear characters. There are 10 characters that are explicitly stated their names and their relationship in long dialogues. On the other hand, 10 unclear characters are not given their identities in each of the dialogues which only state short conversation.

\subsubsection{Explicit Participants}

\section{Example 1}

Samuel : Alif, congratulations. You deserved it, Man.

Alif: $\quad$ Thank you very much. This is because you always help me.

Sinta: I am very happy for you, Alif. Now, that you are the director of the company, I believe the company will develop even faster.

Alif: (replies with a happy tone) Thankyou. I cannot forget your collaboration with me, and I will still need your help.

In that dialogue, it can be seen that the participants are clearly stated in the utterances, which is Samuel, Alif, and Sinta. It can be known from the personal calls/identities such as Samuel, Alif, and Sinta. In this conversation, 
Samuel and Sinta play role as the speaker, On the other hand, Alif plays role as a hearer.

\section{Example 2}

Ditto: Cita, congratulations for being the first winner of the school story telling competition! Excellent. You really did it well.

Cita: Thanks, Ditto.

Ditto: I heard that you will be the representative of our school in the story telling competition of our regency. Is it true?

Cita: Yes, you're right.

Ditto: I hope you will win as well in the next competition.

Cita: I hope so. But I'm nervous.

Ditto: Don't worry, you're a very good story teller. Good luck.

Cita: Thanks. l'll do my best. Wish me luck.

In the dialogue above, the participants is explicitly stated as Ditto and Citta. Two of them play role as friends who congratulate one that become the first winner in school story telling competition. Both of them play as as the speaker and hearer, though Ditto is the one who frequently asks questions to Cita.

\subsubsection{Unclear Participants}

Example 1

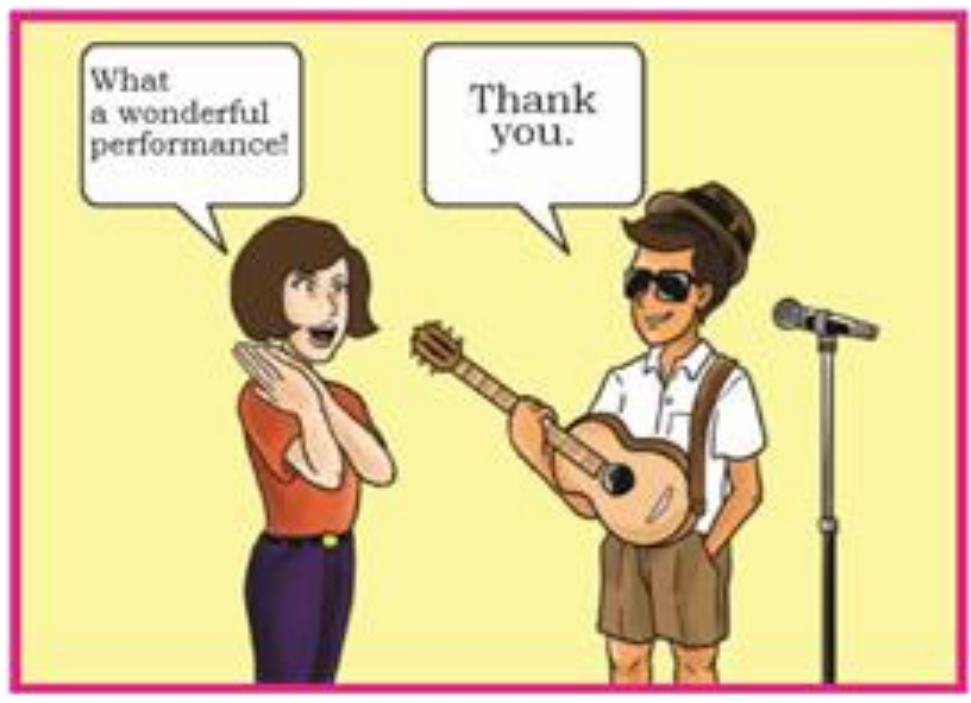

Figure 1. Complimenting a singer

In the example here, there is a man standing with the guitar and microphone. Beside him is a girl expresses her compliment by saying "What a wonderful performance!" with happy expression and excited hand gesture. The girl is the speaker, while the man is the hearer. It is not stated their names, only short dialogue without call/ identity. 
Example 2

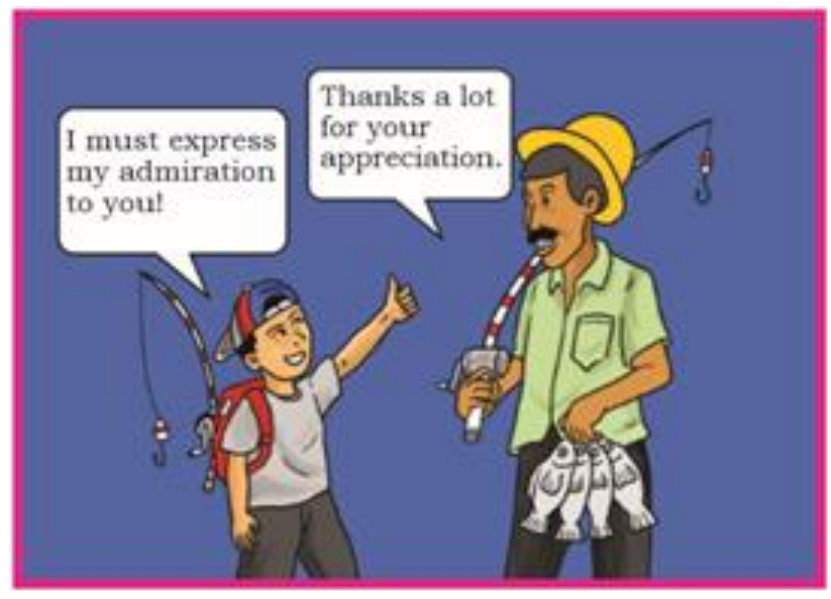

Figure 2. Complimenting a fish catcher

In the dialogue of example 2, it can be seen a boy carrying backpacks and fishing utensil is giving compliment to an older man carrying fishing utensil and fish. The boy as the speaker comments "I must express my admiration to you" which is considered as an expression of compliment. Meanwhile, the older man, the hearer, responses "Thanks a lot for your appreciation." that is recognized as an expression of thanking. There is no call or personal identities of the persons talking.

\subsection{Settings of the Interaction}

Setting refers to the situation and place where the dialogue occurs. It shows the place where interaction happens. Setting is an important element of a context because the place can represent and clarify the content of the dialogue itself. The information regarding the number of setting of interaction happen is shown in the table 3 below.

Table 3. Numbers of Setting of the Interaction in the Dialogues

\begin{tabular}{ccc}
\hline \multicolumn{2}{c}{ Setting } & Total \\
\hline Explicit & Unclear & \\
\hline 3 & 7 & 10 \\
dialogues & dialogues & dialogues \\
\hline
\end{tabular}

Settings of the interaction happen in the dialogues appear explicitly and unclearly. The explicitly stated information of setting is in 3 dialogues. Meanwhile the unclear setting of the dialogue happen is in 6 dialogues. There is no implicit setting of the dialogues, the settings are either stated in the dialogues or left undescribed.

\subsubsection{Explicit Setting of Interaction}

Example

Eny: Please accept my warmest congratulations, Sir.

Alif: It's very kind of you to say so. Thank you

Bintari:I must congratulate you on your success.

Alif: Thank you very much for saying so. 
They all celebrate Alif's success by having lunch together in a simple food stall next to their office. Everybody is happy.

The dialogue above does not state clear information of the setting where the conversation occurs. Both of them only focus on congratulating Alif by stating "Please accept my warmest congratulations, Sir." and "I must congratulate you on your success." without stating the place of conversation happen, but the place is explained below the dialogue which is identified in a simple food stall next to the office.

\subsubsection{Unclear Setting of Interaction}

\section{Example}

Rahmi: Hello. How are things going on, Sinta?

Sinta: Hi. Good, and you?

Rahmi: I'm feeling great today. How was your weekend with your family in Batu?

Sinta: Excellent! We had a lovely time there. You should have gone there with us.

Rahmi: Really? Hey, what a beautiful skirt you are wearing. It matches your blouse.

Sinta: Thanks a lot. My sister bought it for me last month.

Rahmi: Wow! That's wonderful.

Sinta: Oh, Rahmi, can I ask you something?

Rahmi: Oh, sure. Please.

Sinta: Have you finished writing the book we discussed two months ago?

Rahmi: Yes. Come to my room. Look at this. What do you think?

Sinta: Terrific. I like the cover. Let me see the contents. This book is excellent. You really did a great job.

Rahmi: Thanks a lot. You've inspired me to do this.

Sinta: Your publisher should send it to all bookstores here.

Rahmi: Yes, you're right. The publisher will do it for me.

Sinta: Well, that's great. I am proud of you, Rahmi. By the way, I've got to go now. Have a nice day!

Rahmi: You, too.

In this example, it can be seen that the dialogue above happens after Rahmi shows Sinta her writing. "Terrific. I like the cover.", "This book is excellent. You really did a great job.", and "I am proud of you, Rahmi." show expressions of compliment. However, the setting of interaction of this conversation is not clearly explained. Therefore, we can say that the participants are having conversation in non-specific place or setting.

\subsection{Topics of the dialogues}

In a conversation, there must be a topic that is talked about. It is regarding the main idea or content of discussion that interlocutors are having. According to the title of the analyzed unit, congratulating and complimenting, most of the topics discussed is those two. The information related to the number of dialogue about congratulating and complimenting is shown in table 4 below. 
Table 4. Topic of the dialogues

\begin{tabular}{|c|c|c|}
\hline Topic & $\begin{array}{c}\text { Number of } \\
\text { dialogue }\end{array}$ & Dialogue \\
\hline $\begin{array}{l}\text { congratulating on someone's } \\
\text { achievement }\end{array}$ & 4 & $1,2,3,4$ \\
\hline complimenting & 6 & $\begin{array}{c}5,6,7,8,9 \\
10\end{array}$ \\
\hline Total & & 10 dialogues \\
\hline
\end{tabular}

\section{Example 1}

Deni: That's wonderful, Alif.

Alif: Oh, thanks.

Santi: Good for you. Good luck.

Alif: Thank you very much.

Bejo: Well done.

Alif: $\quad$ Thank you for saying so.

Ivan: That was great. You must be very proud of your achievement.

Alif: $\quad$ Thanks. I'm glad you think so. But I still have to learn a lot.

In the above dialogue, Deni, Santi, Bejo, and Ivan are congratulating Alif's achievement. Although it is not described clearly what achievement he got but from the utterances "That's wonderful, Alif.", "Good for you. Good luck.", "That was great. You must be very proud of your achievement." can be concluded that they congratulate someone.

Example 3

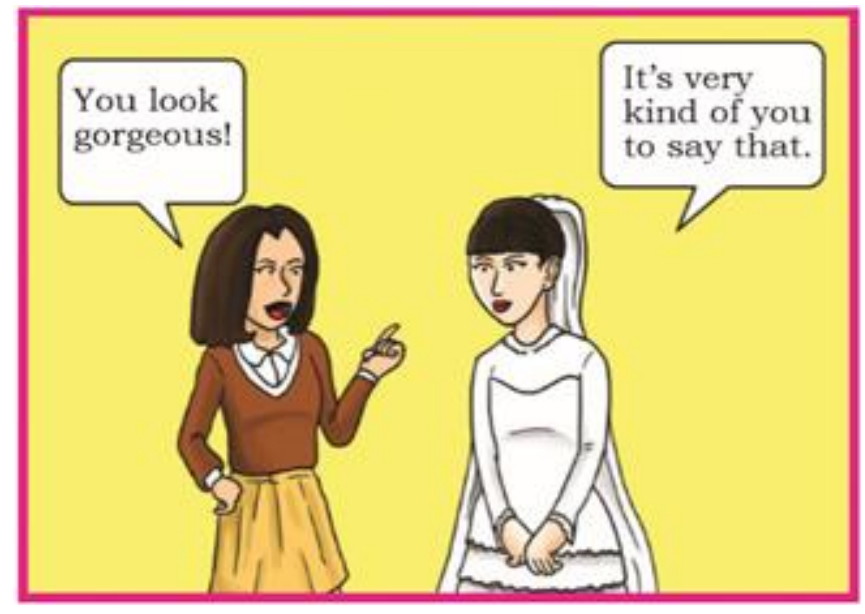

Figure 3. Complimenting a bride

The picture shows complimenting dialogue. It can be assumed from the picture that the situation is in a wedding party. Therefore, the yellow skirtedwoman said "You look gorgeous" to compliment the bride. The expression of complimenting is stated by "You look gorgeous." and response by thanking, which is "It's very kind of you to say that." 


\subsection{Functions of the dialogues}

The last component in context of situation is the function of the interaction in the dialogues. Function refers to the background of why the characters talk to each other. It is found that out of 10 dialogues analyzed, 4 of them are to congratulate someone on his achievement in doing something. Meanwhile, six of them are to compliment someone about his performance, stuff, and look. Below here is the example of complimenting someone and its function of the dialogues.

\section{Example}

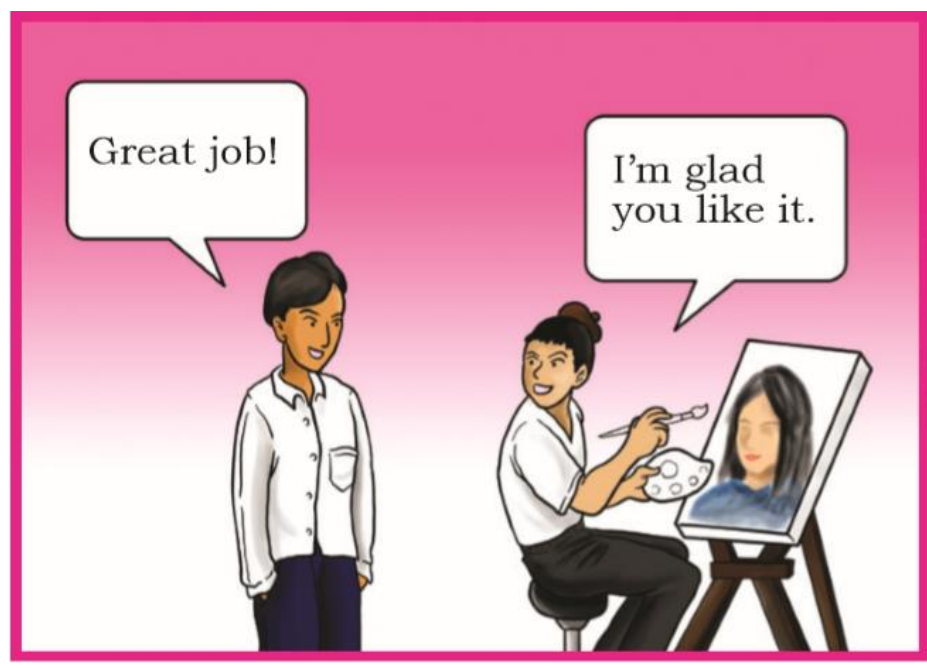

Figure 4. Complimenting an artist

The example above shows a man who compliments an artist who is painting an object. From that short dialogue we can assume that the conversation probably happen in a gallery of art. The function of the dialogue above is to compliment someone's painting. The expression of complimenting is described by "Great job!"

\section{Conclusion}

The analysis of the dialogues in the English textbook related to the context of situation by using Holmes' (1992) framework can be drawn conclusions. Firstly, the participants are described equally. 5 of them are explained explicitly the name or identity of the interlocutors, meanwhile 5 of them are unclear by not giving the name, only showing picture related to it. Secondly, the setting of interaction where the dialogues happen is mostly not stated in the text. They left unclear by giving more explanation on the content, instead of describing the setting of interaction. Thirdly, each of the dialogues represents the unit that is studied. The analysed unit discusses about congratulating and complimenting, therefore whether in the topic or function, both of them talk about congratulating and complimenting. Even though some of the informations in the element of participant, setting, topic and function are unclear, it does not affect the meaning conveyed in the interaction. Hence, the implicit or unclear components portrayed in the dialogues do not bring confusion or problem to the substance of the text. 


\section{Acknowledgments}

This paper is written not merely by our own insight and knowledge. We would like to say our gratitude to our colleagues in Universitas Sebelas Maret who give us another point of view in doing this study. We also thank the lecturers in Universitas Sebelas Maret, especially in English Education for their insights and comments that enhance our comprehension regarding this paper.

\section{References}

Alshumaimeri, Y. A., \& Alzyadi, M. S. (2015). Using material authenticity in the Saudi English textbook design: A content analysis from the viewpoint of EFL teachers. Advances in Language and Literary Studies, 6 (2), 229-241. Ansary, H., \& Babaii, E. (2002). Universal characteristics of EFL/ESL textbook: A step towards systematic textbook evaluation. The Internet TESL Journal, 2, 1-8.

Celce-Murcia M, Dörnyei Z, Thurrell S (1995) A pedagogical framework for communicative competence: A Pedagogically motivated model with content specifications. Issues in Applied Linguistics 6(2): 5-35

Cunningsworth, A. (1995). Choosing your coursebook. Oxford: Heinemann .

Denzin, N. K., \& Lincoln, Y. S. (1994). Handbook of qualitative research. Thousand Oaks, CA: SAGE.

Diepenbroek, L.G. \& Derwing, T.M. (2013). To what extent do popular ESL textbooks incorporate oral fluency and pragmatic development? TESL Canada Journal/Revue TESL Du Canada, 30(7), 1-20.

Holmes, J (2001). An Introduction to Sociolinguistics. London : Longman

Hornby, A.S. (1995). Oxford Advanced Learner Dictionary. London: Oxford University Press

Hymes, D. H. (1972). On communicative competence. In Fauziati (Eds.), Sociolinguistics: Selected readings (pp. 269-293). Harmondsworth: Penguin.

Kim, D., \& Hall, J. K. (2002). The role of an interactive book reading program in the development of second language pragmatic competence. Modern Language Journal, 86, 332-348.

Lichtman, M. (2010). Qualitative research in education: A user's guide. Thousands Oaks, CA: Sage.

Lubis, Y. 1988. Developing Communicative Proficiency in the English as a Foreign Language (EF) Class. Jakarta: P2LPTK.

McKay, S. L. (2003). The Cultural Basis of Teaching English as an International Language. Online Documents at URL http://www.tesol.org/pubs/articles/2003/tm13-4-01.html. [30.06.2004]

Murti, M. N. (2017). Pragmatic Features of Junior High School English Textbook When English Rings A Bell For Grade VII (master's thesis). Universitas Pendidikan Indonesia, Indonesia.

Nuffika, R. A. (2012). A Pragmatic Analysis of Speech Acts of the Main Character in Ryan Fleck's Half Nelson. Universitas Negeri Yogyakarta, Indonesia. 